\title{
Last Chance to Save Olive Ridley Sea-turtles in India*
}

A s early as 1977 , a note of caution was sounded regarding extinction threats to sea-turtles at Gahirmatha, in the coastal strip of the $70 \mathrm{~km}^{2}$ Bitarkanika Wildlife Sanctuary, Orissa State, India. It was pointed out that the once-common and familiar Olive Ridley Sea-turtle (Lepidochelys olivacea) seemed to be losing its fight for survival - ironically enough, in one of the world's largest rookeries (Davis et al., 1978). Olive Ridley Sea-turtles are considered as endangered in the Red Data Book of the World Conservation Union (IUCN).

Gahirmatha in India is one of the four vital arribada (Spanish for arrival, for mass nesting) beaches left in the world - where tens of thousands of Olive Ridley Seaturtles arrive ashore to lay their eggs within the space of a few days. Females lay about 100 or more eggs at a time on sandy beaches. Two such frequented beaches are left on the Pacific coast of Costa Rica and another on the Pacific coast of Mexico. Mexico's other nesting sites have been almost decimated during the present century.

Gahirmatha in Orissa is the only site in the world where more than half a million (actually an estimated 610,000 ) females laid eggs during a single week in March 1991. No other spot has such an unique distinction of seaturtle nesting. The year 1992 witnessed 320,000 and the emerging hatchlings from this nesting were $35,000,000$.

However, the Gahirmatha sea-turtle population is to face very serious threats. For the Government of India intends to develop, about $10 \mathrm{~km}$ from the beach, a major fishing port for shrimp trawlers, a processing plant, and a large-scale prawn culture facility, with establishment of a road through the local mangrove - which is linked with the food-chain for the turtles (Eckert \& Eckert, 1993).

The road problem could be avoided as road facilities exist at nearby Paradeep and Dhamara. Otherwise it could end the nesting site which has no parallel globally. Is there a possibility of increasing the capacity of existing harbours? The planned jetty is expected to take care of around 500 mechanized fishing boats and shrimping trawlers, and it should be remembered that fishing gear takes a heavy toll of adult sea-turtles.

* Presented in the Workshop held on 18-19 December 1993 to discuss the methods of saving our protected areas, held at the M. S. Swaminathan Research Foundation, Madras 600 113, India.
The following are questions that should be considered by the concerned authorities and the legion of Nature lovers in India and elsewhere in the world:

(a) Is the major port for fishing to have only a mild effect on sea-turtles nesting just $10 \mathrm{~km}$ away?

(b) Is it possible to impose regulations to save sea-turtles?

(c) If tourism is made profitable, will it contribute to the economy of the area?

(d) If protein for people is to be harnessed, why ruin the very resource that builds up huge numbers of excess turtle eggs every year (for example, those dug up by turtles nesting later)?

(e) Shall we ever be able to bring back populations of seaturtles when once they have been destroyed?

(f) Why has the Government not cared to initiate studies on the environmental impact of its plans and make the findings public?

(g) Has the Government any policy on sea-turtles?

(h) Have we ever realized the ravaging mortality-rates of sea-turtles from incidental catches by shrimpers?

It is a pity that India seems keen to undertake what could amount to abandoning the world's largest aggregation of Olive Ridley Sea-turtles at Gahirmatha. Hence, the Author earnestly seeks global environmental and conservation support to ensure that the world's largest nestingground of Olive Ridley Sea-turtles, finding shelter at the Gahirmatha habitat in Orissa State, are given a new lease of life - especially as the species is threatened with extinction.

\section{REFERENCES}

Davis, T. Antony, Bedi, Rajesh \& Oza, G. M. (1978). Sea-turtle faces extinction in India. Environmental Conservation, 5(3), pp. 211-2, 2 figs.

ECKerT, KAREN L. \& ECKERT, SCOTT A. (1993). 'Urgent and Immediate Action' needed to safeguard the world's largest aggregation of nesting sea-turtles. Marine Turtle Newsletter, 63, pp. 1-2.

Gunavant M. Oza

General Secretary of INSONA and President, Foundation for Environmental Awareness Oza Building, Salatwada

Baroda 390001 , India.

\section{Pakistan to Protect 'Throne-room of Mountain Gods'}

$\mathrm{R}$

eacting recently to environmental pressures on one of the most outstanding mountain regions in the world, the then caretaker Prime Minister of Pakistan, Mr Moeen Qureshi, approved in principle the declaration of a new national park in the Central Karakorum mountains in Baltistan. The area, better known as Concordia, contains the greatest concentration of high peaks in the world, including K-2, the world's second-highest mountain.

The Karakorums, along with the Pamirs, the Hindu Kush, the Kun Lun, and the Himalayan ranges, intersect to form a complex geographical feature known as the Pamir Knot. This phenomenon, which is the result of a "collision of continents', has resulted in the formation of the world's loftiest and most dramatic example of mountain-building, which has been well-called 'The Throne-room of the Mountain Gods'. The ongoing geological evolution of the area is of exceptional scientific interest.
Together with the Himalayan ranges, the Karakorum range accounts for 96 of Earth's 109 highest mountains. Baltistan alone contains 10 of the world's 30 highest peaks. The area not only boasts some of the finest alpine sights in the world, but is also the home of the greatest extent of glaciers outside the polar regions, namely the Siachen (74 $\mathrm{km})$, the Baltoro $(58 \mathrm{~km})$, and the Biafo/Hispar glaciers (59 $\mathrm{km})$.

$\mathrm{K}-2$, which is short for Karakorum 2, rises to a height of 8,611 metres and earned its peculiar name because it was the second peak measured by Colonel T.G. Montgomerie, who 'discovered' it in 1856 . A recent geological report speculates that over the next 100 years, the height of $\mathrm{K}-2$ will approach that of the Mount Everest, the highest peak in the world. This calculation is based upon the phenomenon of the upthrust of land which could result in the rise in height of the mountain over the time-span of a century. 